\title{
KEPUTUSAN PENGAMBILAN KREDIT PEMILIKAN RUMAH (KPR)PENGARUH BRAND AWARENESS, PHYSICAL EVIDENCE DAN SERVICE QUALITY PADA PT. BTN (PERSERO) Tbk
}

\author{
Hillary Threcia ${ }^{1}$ \\ Y. Budi Hermanto ${ }^{2}$ \\ Maria Widyastuti ${ }^{3}$ \\ ${ }^{1}$ Universitas Katolik Darma cendika, Indonesia \\ threciahillary@gmail.com \\ ${ }^{2}$ Universitas Katolik Darma cendika, Indonesia \\ y.budiher@gmail.com \\ ${ }^{3}$ Universitas Katolik Darma cendika, Indonesia \\ maria.widyastuti@ukdc.ac.id
}

\begin{abstract}
This research aims to determine the effect of brand awareness, physical evidence and service quality on mortgage decisions at Bank BTN Branch Office Surabaya Bukit Darmo. The sampling method are purposive sampling method with sample size of 100 respondents. The results showed that: (1) there is a positive and significant impact of brand awareness on the decisions to make KPR at Bank BTN Surabaya Bukit Darmo Branch office (2) There is a positive and significant effect of physical evidence ondecision to make KPR at Bank BTN Surabaya Bukit Darmo Branch Office (3) there is a positive and significant effect of service quality on the decisions to make KPR at Bank BTN Surabaya Bukit Darmo Branch Office; and the regression coefficient is 0.314. (4) The influence of brand awareness, physical evidence and service quality on mortgage decisions at Bank BTN Surabaya Bukit Darmo Branch Office (adjusted R2) is 79.7\%.
\end{abstract}

Keywords: Brand Awareness, Physical Evidence, Service Quality, Purchasing Decisions

\section{PENDAHULUAN}

Tempat tinggal merupakan salah satu kebutuhan pokok makhluk hidup selain sandang dan pangan. Tingginya tingkat kebutuhan menyebabkan masyarakat kesulitan untuk membeli rumah secara tunai atau kontan. Pada tahap inilah, masyarakat memanfaatkan sektor perbankan sebagai pihak ketiga dalam menyalurkan dana pembiayaan kredit pemilikan rumah (KPR). Sektor perbankan telah diberi kewenangan oleh pemerintah untuk menjadi penyalur fasilitas kredit pemilikan rumah (KPR).
Salah satunya yaitu PT. Bank Tabungan Negara, Tbk yang telah ditunjuk oleh Pemerintah Indonesia sejak tahun 1974 melalui Surat Menteri Keuangan RI No. B-49/MK///1974 sebagai wadah pembiayaan proyek perumahan untuk rakyat. Pada saat itu, Bank BTN merupakan satu-satunya dan bank pertama yang mempunyai konsentrasi penuh pada penyalur pembiayaan KPR sehingga mencerminkan visi Bank BTN, yakni, "Terdepan dan terpercaya dalam memfasilitasi sektor perumahan dan jasa layanan keuangan keluarga.” 
Tabel 1

Realisasi Penyaluran Dana FLPP Tahun 2015-2020 (Bulan berjalan)

*Data dikoleksi pada tanggal 27 Juni 2020

\begin{tabular}{|c|l|r|r|r|r|r|r|r|}
\hline NO & BANK PELAKSANA & $\mathbf{2 0 1 5}$ & $\mathbf{2 0 1 6}$ & $\mathbf{2 0 1 7}$ & $\mathbf{2 0 1 8}$ & $\mathbf{2 0 1 9}$ & $\mathbf{2 0 2 0}$ & TOTAL \\
\hline $\mathbf{1}$ & BTN & 66.563 & 43.821 & 0 & 22.737 & 29.922 & 38.627 & $\mathbf{2 0 1 . 6 7 0}$ \\
\hline $\mathbf{2}$ & BTN Syariah & 6.220 & 4.112 & 0 & 1.074 & 3.722 & 6.089 & $\mathbf{2 1 . 2 1 7}$ \\
\hline $\mathbf{3}$ & BRI Syariah & 1.449 & 2.917 & 5.703 & 6.842 & 7.672 & 3.784 & $\mathbf{2 8 . 3 6 7}$ \\
\hline $\mathbf{4}$ & ASBANDA (33 BPD) & 782 & 3.950 & 10.238 & 13.988 & 17.520 & 10.759 & $\mathbf{5 7 . 2 3 7}$ \\
\hline $\mathbf{5}$ & BNI & 1.098 & 1.255 & 1.456 & 7.214 & 9.743 & 7.013 & $\mathbf{2 7 . 7 7 9}$ \\
\hline $\mathbf{6}$ & Artha Graha & 191 & 2.359 & 5.579 & 3.885 & 4.811 & 981 & $\mathbf{1 7 . 8 0 6}$ \\
\hline $\mathbf{7}$ & Mandiri & 26 & 16 & 166 & 994 & 1.855 & 1.021 & $\mathbf{4 . 0 7 8}$ \\
\hline $\mathbf{8}$ & Bukopin & 0 & 0 & 0 & 0 & 0 & 0 & $\mathbf{0}$ \\
\hline $\mathbf{9}$ & BRI & 160 & 20 & 603 & 1.161 & 2.206 & 1.793 & $\mathbf{5 . 9 4 3}$ \\
\hline $\mathbf{1 0}$ & Mandiri Syariah & 0 & 0 & 0 & 0 & 0 & 0 & $\mathbf{0}$ \\
\hline $\mathbf{1 1}$ & Mayora & 0 & 19 & 18 & 0 & 0 & 0 & $\mathbf{3 7}$ \\
\hline $\mathbf{1 2}$ & BANK KEB HANA & 0 & 0 & 0 & 31 & 216 & 33 & $\mathbf{2 8 0}$ \\
\hline $\mathbf{1 3}$ & BRI AGRO & 0 & 0 & 0 & 10 & 168 & 235 & $\mathbf{4 1 3}$ \\
\hline $\mathbf{1 4}$ & BTPN & 0 & 0 & 0 & 3 & 0 & 0 & $\mathbf{3}$ \\
\hline \multicolumn{1}{|c|}{ TOTAL } & $\mathbf{7 6 . 4 8 9}$ & $\mathbf{5 8 . 4 6 9}$ & $\mathbf{2 3 . 7 6 3}$ & $\mathbf{5 7 . 9 3 9}$ & $\mathbf{7 7 . 8 3 5}$ & $\mathbf{7 0 . 3 3 5}$ & $\mathbf{3 6 4 . 8 3 0}$ \\
\hline
\end{tabular}

Sumber data: www.ppdpp.id, 2020

Pada Tabel 1, realisasi penyaluran Fasilitas Likuiditas Pembiayaan Perumahan (FLPP) periode tahun 2015 sampai dengan tahun 2020, Bank BTN telah melayani realisasi penyaluran dana FLPP sebanyak 201.670 unit, angka yang lebih besar dibandingkan bank lainnya.Dari data diatas, dapat dikatakan keputusan pengambilan KPR di Bank BTN masih cukup besar. Beberapa faktor yang dapat mempengaruhi peningkatan jumlah pengambilan KPR di Bank BTN, diantaranya adalah membangun kesadaran konsumen terhadap merek yang perusahaan dan physical evidence (bukti fisik) pada bangunan juga service quality (kualitas pelayanan) yang diberikan. Banyaknya pesaing dalam sektor perbankan yang juga melayani pembiayaan KPR, memacu Bank BTN agar lebih kreatif dalam strategi pemasaran untuk meningkatkan kesadaran masyarakat terhadap keberadaan Bank BTN Menurut Wilson dalam Wibowo (2017: 233), menyatakan bahwa brand memainkan peranan penting dalam mempengaruhi keputusan pembelian konsumen. Selama proses pengambilan keputusan, konsumen memilih produk dan merek yang mereka sadari atau ingat. Ini merupakan setting pertimbangan yang penting, karena sebuah merk yang bukan bagian dari pertimbangan tidak akan dipilih. Dengan kata lain, merk yang memiliki top of mind yang tinggi memiliki kemungkinan paling tinggi untuk dipilih oleh 
konsumen sehingga konsumen melakukan pembelian produk. Ditunjuknya Bank BTN sebagai bank pertama penyalur pembiayaan KPR menciptakan merek (brand) yang selalu dikaitkan dengan pembiayaan KPR. Dalam upaya meningkatkan citra merek perusahaan, diperlukan penanaman keberadaan merek (brand awareness), sehingga nasabah dapat membedakan produk antar satu merek dengan produk merek yang lain (Hidayah \& Prabawani, 2016: 459). Selama 6 tahun berturutturut Bank BTN bertahan pada posisi pertama dalam penelitian yang dilakukan oleh lembaga riset independen, Frontier Group pada kategori "Top Brand Index Kategori Banking and Finance Produk KPR'. Hal ini tentu menjadi sebuah kebanggan dan sebuah bukti citra perusahaan bahwa Bank BTN masih dipercaya oleh masyarakat Indonesia sebagai penyalur pembiayaan KPR yang terbaik. Untuk dapat mempertahankan gelar tersebut perlu didukung dengan menyediakan physical evidence dan service quality terbaik yang diberikan kepada nasabah.Menurut Komari, et al. (2020), physical evidence menjadi penting terutama di era sekarang ini. Pada era digitalisasi ini, penjualan melalui media sosial memang sangat marak, namun keberadaan gedung dan lokasi perusahaan yang tepat sangat mempengaruhi pemasaran, dalam hal ini, untuk meyakinkan pelanggan mengambil KPR di Bank BTN. Lokasi Bank BTN Kantor Cabang Surabaya Bukit Darmo saat ini beralamat di jalan HR. Muhammad, Surabaya, lokasi ini dapat dikatakan lokasi yang sangat strategis karena berada di pinggir jalan raya dilengkapi dengan lampu LED sign Bank BTN berwarna kuning sehingga mudah ditemukan dan dikenali oleh nasabah. Selain physical evidence, service quality juga menjadi salah satu faktor yang dapat meningkatkan keputusan pembelian konsumen. Bagi perusahaan jasa, dalam upaya mempertahankan atau bahkan meningkatkan jumlah konsumen mereka, mereka harus menemukan cara untuk mengungguli pesaing dan mengungguli harapan konsumen mereka. (Hengstum, 2015). Bank BTN berhasil meraih penghargaan berdasarkan riset yang dilakukan Biro Riset Infobank bersama Marketing Research Indonesia (MRI) pada tahun 2018-2019 pada kategori Satisfaction Loyalty Engagement (SLE) Index, dimana riset ini dinilai berdasarkan pelayanan yang diberikan oleh petugas Bank BTN kepada nasabahnya (infobanknews.com). Beberapa penelitian sebelumnya mengenai pengaruh variabel Brand Awareness, Physizal Evidence dan Service Quality 
terhadap keputusan pembelian menunjukkan hasil yang berbeda pada masing-masing variabel yang menyebabkan adanya Research Gap. Oleh karena itu dikemukakan Research Gap pada penelitian ini adalah Brand awareness dalam penelitian yang dilakukan oleh Muthiah dan Setiawan (2019) menunjukkan berpengaruh negatif terhadap keputusan pembelian. Sedangkan penelitian yang dilakukan oleh Navaril dan Usman (2020) menunjukkan bahwa brand awareness berpengaruh positif dan signifikan terhadap keputusan pembelian.Physical Evidence dalam penelitian yang dilakukan oleh Qorizah dan Prabowo (2019) menunjukkan berpengaruh negatif terhadap keputusan pembelian. Berbeda dengan penelitian yang dilakukan oleh Sara, et al. (2019) yang menyatakan bahwa physical evidence berpengaruh positif terhadap keputusan pembelian.Service quality dalam penelitian yang dilakukan oleh Laksmi (2019) menunjukkan berpengaruh negatif terhadap keputusan pembelian. Sedangkan penelitian yang dilakukan oleh Tran, et al. (2020) menunjukkan bahwa service quality berpengaruh positif dan signifikan terhadap keputusan pembelian.Tujuan penelitian ini adalah untuk mengetahui pengaruh Brand Awareness, Physical Evidence dan Service Quality terhadap keputusan pengambilan KPR pada Bank BTN

Kantor Cabang Surabaya Bukit Darmo.

Menurut Tjiptono (2014: 21)

"keputusan pembelian adalah sebuah proses dimana konsumen mengenal masalahnya, mencari informasi mengenai produk atau merek tertentu dan mengevaluasi secara baik masingmasing alternatif tersebut agar dapat memecahkan masalahnya, yang kemudian mengarah kepada keputusan pembelian.'Kemudian menurut Kotler \& Armstrong (2014: 151), keputusan pembelian adalah tahap dalam proses pengambilan keputusan pembeli di mana konsumen benar-benar membeli Indikator keputusan pembelian menurut Thompson dalam Baskara dan Hariyadi (2014) yaitu: 1) Sesuai kebutuhan, 2) Mempunyai manfaat, 3) Ketepatan dalam membeli produk, dan 4) Pembelian berulang.Menurut Hasbun dan Ruswanty (2016), kesadaran merk atau brand awareness adalah kemampuan merk yang muncul di benak konsumen ketika mereka berpikir tentang produk tertentu dan seberapa mudah sebuah produk muncul.Menurut Ekhveh dan Darvishi (2015), brand awareness merupakan kemampuan pelanggan untuk mengenali merk dalam berbagai kondisi yang mencerminkan kesadaran mereka terhadap merk. Indikator brand awareness menurut Keller dalam Winardi (2017) sebagai 
berikut: 1) Recall, 2) Recognition, 3) Purchase, dan 4) Consumption.Menurut Kotler dalam Marcellina dan Billy (2017), physical evidence adalah bukti yang dimiliki oleh penyedia jasa yang ditujukan kepada konsumen sebagai usulan nilai tambah konsumen. Sedangkan menurut pendapat ahli lain, Nurhayati dalam Sabrilia, et al. (2016), mengemukakan bahwa physical evidence adalah sarana fisik yang secara nyata turut mempengaruhi keputusan untuk membeli dan menggunakan barang maupun jasa.Indikator physical evidence menurut Zeithaml, Bitner dan Gremler yang dikutip oleh Sara, et al. (2019) yaitu: 1) Fasilitas eksterior, 2) Fasilitas Interior, dan 3) Fasilitas lainnya. Menurut Rosica dan Wibowo (2016), service quality adalah seberapa jauh perbedaan antara harapan dan kenyataan para pelanggan atas layanan yang diterima. Definisi service quality menurut Blythe dalam Foya (2015: 47), adalah kemampuan perusahaan untuk memenuhi atau melampaui ekspektasi pelanggan. Menurut Kotler dan Keller (2016: 156) service quality merupakan totalitas fitur dan karakteristik layanan yang menunjukkan kemampuan perusahaan untuk memenuhi kebutuhan konsumen. Indikator service quality menurut Zeithaml, et al. dalam Nazwirman dan Zain (2017), sebagai berikut: 1) Tangibles, 2) Reliability, 3)
Responsiveness, 4) Assurance, dan 5) Empathy.

\section{METODE PENELITIAN}

Jenis penelitian yang digunakan adalah penelitian kuantitatif. Variabel independen yang diteliti pada penelitian ini adalah Brand Awareness, Physical Evidence, dan Service Quality. Sedangkan variabel dependen adalah Keputusan Pembelian. Tehnik pengambilan sampel yang digunakan non probability sampling, dengan metode purposive sampling, yaitu teknik penentuan sampel dengan pertimbangan tertentu.Syarat sampel dalam penelitian ini adalah responden yang: 1)memiliki pinjaman KPR di Bank BTN. 2) berusia diatas 25 tahun. Mengutip Roscoe dalam Sugiyono $(2019 ; 144)$, penentuan jumlah sampel yang layak dalam penelitian adalah antara 30 sampai dengan 500 responden. dalam penelitian ini jumlah sampel ditentukan menggunakan rumus Slovin,dengan jumlah 7074 nasabah, sehingga didapatkan jumlah sampel sebesar 98,60 yang dibulatkan menjadi 100 responden. Penelitian ini menggunakan metode pengumpulan data primer dan sekunder. Data primer pada penelitian ini berasal dari survei penyebaran kuesioner pada nasabah produk KPR Bank BTN yang dikumpulkan secara khusus dan berkaitan langsung tentang permasalahan yang diteliti. 


\section{KERANGKA MODEL}

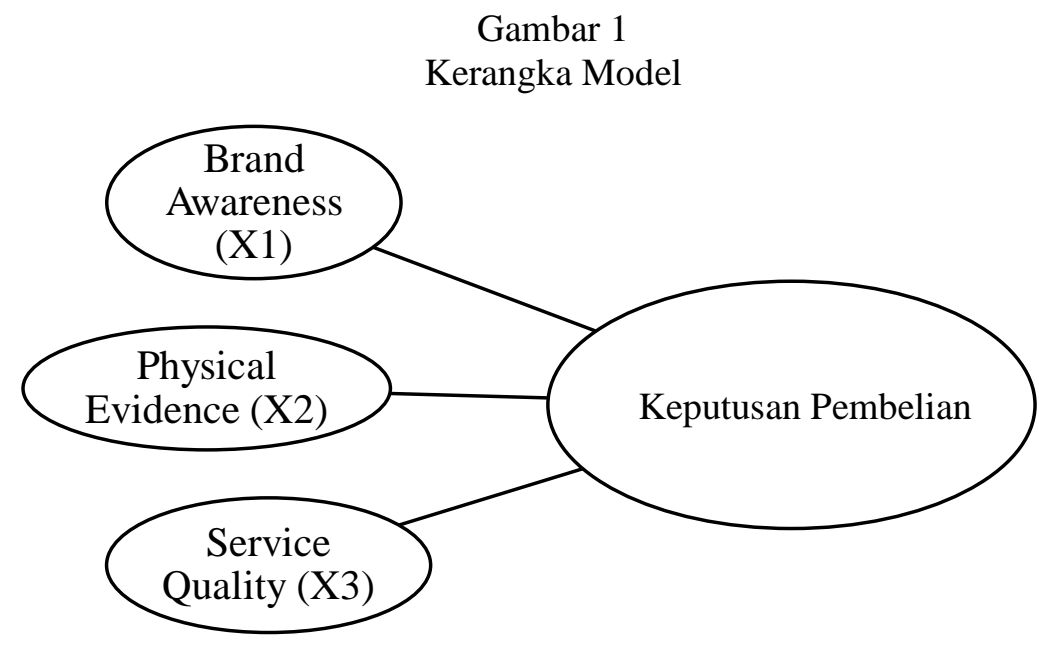

\section{DEFINISI OPERASONAL VARIABEL}

Tabel 1

Definisi Operasional untuk Variabel

\begin{tabular}{|c|c|c|c|}
\hline Variabel & $\begin{array}{l}\text { Definisi } \\
\text { Variabel }\end{array}$ & Indikator & Skor \\
\hline $\begin{array}{l}\text { Brand } \\
\text { Awareness }\end{array}$ & $\begin{array}{l}\text { Brand awareness } \\
\text { merupakan tolak ukur } \\
\text { aksesibilitas merek Bank } \\
\text { BTN sebagai bank penyalur } \\
\text { pembiayaan KPR dalam } \\
\text { memori nasabah sehingga } \\
\text { mereka dapat mengenali } \\
\text { Bank BTN dalam berbagai } \\
\text { kondisi yang } \\
\text { mencerminkan kesadaran } \\
\text { mereka terhadap } \\
\text { keberadaan Bank BTN }\end{array}$ & $\begin{array}{l}\text {-Recall } \\
\text {-Recognition } \\
\text {-Purchase } \\
\text { - Consumption }\end{array}$ & $\begin{array}{l}\text { Skoring: } \\
\text { Sangat tidak setuju=1 } \\
\text { Tidak setuju=2 } \\
\text { Kurang Setuju=3 } \\
\text { Setuju=4 } \\
\text { Sangat setuju=5 } \\
\\
\text { Kriteria Penilaian } \\
\text { Sangat kuat }=80 \%- \\
100 \%\end{array}$ \\
\hline $\begin{array}{l}\text { Physical } \\
\text { evidence }\end{array}$ & $\begin{array}{l}\text { Physical evidence } \\
\text { merupakan sarana fisik } \\
\text { dalam bentuk nyata yang } \\
\text { ditawarkan oleh Bank BTN } \\
\text { kepada nasabah sehingga } \\
\text { dapat menunjang } \\
\text { kenyamanan bertransaksi di } \\
\text { Bank BTN. }\end{array}$ & $\begin{array}{l}\text { Fasilitas eksterior, } \\
\text { indikatornya: bangunan } \\
\text { perusahaan, lahan parkir. } \\
\text {-Fasilitas interior, } \\
\text { indikatornya: kursi antrian, } \\
\text { meja slip. } \\
\text { Fasilitas lainnya, indikatornya: } \\
\text { brosur produk simpanan, } \\
\text { seragam personel. }\end{array}$ & $\begin{array}{l}\text { Kuat }=60 \%-79.9 \% \\
\text { Sedang }=40 \%- \\
59.9 \% \\
\text { Rendah }=20 \%- \\
39.9 \% \\
\text { Sangat rendah 0\%- } \\
19.9 \% \text { (Sugiyono, } \\
2019 \text { ) }\end{array}$ \\
\hline
\end{tabular}


FAKULTAS EKONOMI DAN BISNIS UNIVERSITAS WIRARAJA - MADURA

\begin{tabular}{|c|c|c|c|}
\hline Variabel & $\begin{array}{l}\text { Definisi } \\
\text { Variabel }\end{array}$ & Indikator & Skor \\
\hline $\begin{array}{l}\text { Service } \\
\text { quality }\end{array}$ & $\begin{array}{l}\text { Service quality merupakan } \\
\text { upaya yang dilakukan oleh } \\
\text { Bank BTN untuk melayani } \\
\text { kebutuhan properti nasabah } \\
\text { dengan tindakan yang } \\
\text { melampaui harapan } \\
\text { nasabah tersebut. }\end{array}$ & $\begin{array}{l}\text {-Tangibles, indikatornya: slip } \\
\text { transaksi, peralatan tulis. } \\
\text { Reliability, indikatornya: } \\
\text { standar pelayanan transaksi } \\
\text { yang jelas. } \\
\text {-Responsiveness, indikatornya: } \\
\text { pelayanan cepat dan tepat, } \\
\text { merespon keluhan nasabah. } \\
\text { - Assurance, indikatornya: } \\
\text { memberikan jaminan } \\
\text { kerahasiaan data nasabah. } \\
\text { - Empathy, indikatornya: } \\
\text { melayani dengan ramah, } \\
\text { memiliki sopan santun yang } \\
\text { baik. }\end{array}$ & \\
\hline $\begin{array}{l}\text { Keputusan } \\
\text { Pembelian }\end{array}$ & $\begin{array}{l}\text { Keputusan pembelian } \\
\text { adalah tahap dimana calon } \\
\text { debitur KPR di Bank BTN } \\
\text { setelah melalui proses } \\
\text { pencarian informasi dan } \\
\text { evaluasi mengenai } \\
\text { perumahan yang akhirnya } \\
\text { menimbulkan niat atau } \\
\text { keinginan untuk } \\
\text { mengambil kredit KPR } \\
\text { melalui Bank BTN }\end{array}$ & $\begin{array}{l}\text { - Sesuai kebutuhan } \\
\text { - Mempunyai manfaat. } \\
\text { - Ketepatan dalam membeli } \\
\text { produk } \\
\text { - Pembelian berulang }\end{array}$ & \\
\hline
\end{tabular}

Sumber: Data diolah peneliti 2020

\section{HASIL PENELITIAN}

Karakteristik responden yang diamati dalam penelitian ini meliputi usia dan pekerjaan. Deskripsi karakteristik responden berdasarkan usia disajikan pada tabel 2 .

Tabel 2 menunjukkan bahwa responden dengan usia antara 25 - 30 tahun sebanyak 24 orang (24\%), responden dengan usia antara 31 - 35 tahun sebanyak 39 orang (39\%), reponden dengan usia antara 36 - 40 tahun sebanyak 22 orang $(22 \%)$ dan responden usia diatas 40 tahun sebanyak 15 orang (15\%). Data ini menunjukkan mayoritas responden berusia $31-35$ tahun sebanyak 39 orang (39\%, hal ini dapat diterima karena responden pada usia 3135 tahun cenderung telah memiliki kondisi keuangan yang stabil sehingga dapat dikatakan mampu secara finansial. Deskripsi karakteristik responden berdasarkan pekerjaan disajikan pada tabel 3. 
Tabel 2

Karakteristik Responden Berdasarkan Usia

\begin{tabular}{|c|c|c|}
\hline Usia & Frequency & Percent \\
\hline $25-30$ tahun & 24 & 24,00 \\
\hline $31-35$ tahun & 39 & 39,00 \\
\hline $35-40$ tahun & 22 & 22,00 \\
\hline$>40$ tahun & 15 & 15,00 \\
\hline Total & 100 & 100 \\
\hline
\end{tabular}

Sumber: Data primer, 2020

Tabel 3

Karakteristik Responden Berdasarkan Pekerjaan

\begin{tabular}{|c|c|c|}
\hline Pekerjaan & Frequency & Percent \\
\hline PNS & 5 & 5,00 \\
\hline Karyawan BUMN & 19 & 19,00 \\
\hline Wiraswasta & 14 & 14,00 \\
\hline Wirausaha & 47 & 47,00 \\
\hline Lainnya & 15 & 15,00 \\
\hline Total & 100 & 100 \\
\hline
\end{tabular}

Sumber: Data primer, 2020

Tabel 3 terbagi atas 5 kategori pekerjaan yang menunjukkan bahwa responden yang bekerja sebagai PNS sebanyak 5 orang $(5 \%)$, responden yang bekerja sebagai karyawan BUMN sebanyak 19 orang $(19 \%)$, responden yang berkerja sebagai wiraswasta sebanyak 14 orang (14\%), responden yang bekerja sebagai wirausaha sebanyak 47 orang (47\%), dan responden dengan pekerjaan lainnya sebanyak 15 orang (15\%). Data ini menunjukkan bahwa mayoritas responden bekerja sebagai wirausaha yakni sebanyak 47 orang (47\%), hal ini dapat diterima karena nasabah yang bekerja pada bidang wirausaha cenderung memiliki tingkat penghasilan yang lebih besar dibandingkan bidang pekerjaan lainnya.

\section{PEMBAHASAN}

Hasil uji validitas diketahui bahwa seluruh item pernyataan pada variabel Brand Awarenes,Physical Evidence, Service Quality dan Keputusan Pembelian valid karena memiliki $r$ hitung > 0,3 sehingga dapat dikatakan valid, sesuai dengan teori Sugiyono.Hasil uji reliabilitas menunjukkan seluruh item pernyataan dikatakan reliabel karena memiliki nilai koefisien Guttman Split-Half> 0,8, sehingga dapat dikatakan reliabel. Dari hasil uji validitas dan reabilitas maka kuesnair memenuhi syarat untuk disebarkan pada responden.

Uji asumsi klasik yang digunakan: 1) Uji normalitas menunjukkan bahwa nilai sig 0,100>5\% Maka dapat disimpulkan 
bahwa model regresi memenuhi asumsi normalitas dan data terdistribusi dengan normal. 2) Uji multikolinearitas menunjukkanbahwa tolerance value> 0,1 sedangkan nilai VIF $<10$, artinya tidak terjadi gejala multikolinieritas antar variabel independent pada model regresi. 3) Uji Heteroskedastisitas menunjukkanbahwa sebaran titik - titik berada di atas dan dibawah angka 0 pada sumbu Y dan tidak membentuk pola yang jelas maka tidak terjadi heteroskedastisitas pada model regresi. Hasil uji kelayakan model dapat dilihat nilai signifikan F 0,000 <0,05 maka dapat disimpulkan bahwa model regresi pada penelitian ini layak untuk diteliti.

Hasil regresi linier bergandadapat dilihat persamaan regresi linear berganda antara variabel X yaitu Brand Awareness (X1), Physical Evidence (X2) dan Service Quality (X3) terhadap variabel Y yaitu Keputusan Pembelian, dengan persamaan sebagai berikutY $=0,147+$ $0,483 X 1+0,102 X 2+0,314 X 3$. Hasil perhitungna koefisien determinandapat disimpulkan bahwa hasil adjusted $R$ square sebesar 0,797 atau 79,7\% yang artinya variabelbrand awareness, physical evidence dan service quality berkontribusi sangat kuat terhadap variabel Keputusan Pembelian.

Hasil uji t menunjukkan nilai signifikansi variabel brand awareness $0,000<0,05$ sehingga dapat $\begin{array}{llr}\text { disimpulkan } & \text { Brand } & \text { Awareness } \\ \text { berpengaruh } & \text { signifikan } & \text { terhadap }\end{array}$

Keputusan Pengambilan KPR pada Bank BTN Kantor Cabang Surabaya Bukit Darmo. Sedangkan nilai signifikansi variabel physical evidence $0,034<0,05$ dengan demikian dapat disimpulkan bahwa Physical Evidence berpengaruh signifikan terhadap Keputusan Pengambilan KPR pada Bank BTN Kantor Cabang Surabaya Bukit Darmo. Nilai signifikansi variabel service quality $0,001<0,05$, hasil tersebut dapat disimpulkan bahwa Service Quality berpengaruh signifikan terhadap Keputusan Pengambilan KPR pada Bank BTN Kantor Cabang Surabaya Bukit Darmo.Berdasarkan hasil penelitian Brand Awareness berpengaruh signifikan terhadap keputusan pengambilan KPR pada Bank BTN Kantor Cabang Surabaya Bukit Darmo. Penelitian ini mendukung penelitian yang dilakukan oleh Navaril dan Usman (2020:20) yang menyatakan bahwa variabel brand awareness mempunyai pengaruh positif dan signifikan terhadap keputusan pembelian melalui media sosial Instagram. Hasil penelitian ini sesuai dengan penelitian yang dilakukan di Bank BTN Kantor Cabang Surabaya Bukit Darmo dikarenakan dengan terciptanya brand awareness, diharapkan nasabah dapat 
mengingat dan mengenali merek Bank BTN sebagai bank penyalur pembiayaan KPR sehingga dapat mempengaruhi keputusan pengambilan KPR nasabah pada Bank BTN Kantor Cabang Surabaya Bukit Darmo. Oleh karena itu, brand awareness berpengaruh signifikan terhadap keputusan pengambilan KPR pada Bank BTN Kantor Cabang Surabaya Bukit Darmo. Hasil penelitian Physical Evidence berpengaruh positif dan signifikan terhadap keputusan pengambilan KPR pada Bank BTN Kantor Cabang Surabaya Bukit Darmo.Penelitian ini mendukung penelitian yang dilakukan oleh Sara, et al. (2019: 16) yang menyatakan bahwa physical evidence berpengaruh positif terhadap keputusan pembelian konsumen di Café Infinito Culinery Bandung. Hasil penelitian ini sesuai dengan penelitian yang dilakukan di Bank BTN Kantor Cabang Surabaya Bukit Darmo dimana Bank BTN Kantor Cabang Surabaya Bukit Darmo yang terletak pada lokasi yang mudah ditemukan selain itu Bank BTN Kantor Cabang Surabaya Bukit Darmo juga menyediakan fasilitas yang dapat menunjang proses transaksi dengan lengkap, sarana parkir yang luas, ruang banking hall yang nyaman serta tersedianya formulir transaksi dan informasi produk. Oleh karena itu, physical evidence berpengaruh signifikan terhadap keputusan pengambilan KPR pada Bank BTN Kantor Cabang Surabaya Bukit Darmo. Penelitian Service Qualitymenunjukkan berpengaruh positif dan signifikan terhadap keputusan pengambilan KPR pada Bank BTN Kantor Cabang Surabaya Bukit Darmo.Penelitian ini mendukung penelitian yang dilakukan oleh Tran, et al. (2020: 6) yang menyatakan bahwa service quality berpengaruh positif dan signifikan terhadap keputusan pembelian buah segar di Vietnam. Hasil penelitian ini sesuai dengan penelitian yang dilakukan di Bank BTN Kantor Cabang Surabaya Bukit Darmo dimana petugas yang dimiliki Bank BTN Kantor Cabang Surabaya Bukit Darmo selalu melayani nasabah dengan menyediakan bukti fisik yang dapat menunjang kenyamanan transaksi, sikap dapat dipercaya, kehandalan, empati yang tinggi juga pelayanan yang dapat membuat nasabah merasa aman dan terjamin kerahasiaan datanya saat bertransaksi di Bank BTN Kantor Cabang Surabaya Bukit Darmo. Oleh karena itu, service quality berpengaruh signifikan terhadap keputusan pengambilan KPR pada Bank BTN Kantor Cabang Surabaya Bukit Darmo. 


\section{FAKULTAS EKONOMI DAN BISNIS UNIVERSITAS WIRARAJA - MADURA}

\section{SIMPULAN}

Berdasarkan hasil penelitian dan analisis data mengenai pengaruhbrand awareness, physical evidence dan service quality terhadap keputusan pembelian, maka dapat diambil beberapa kesimpulan sebagai berikut: 1) Brand Awareness berpengaruh signifikan terhadap keputusan pengambilan KPR pada Bank BTN Kantor Cabang Surabaya Bukit Darmo. 2) Physical Evidenceberpengaruhdan signifikan terhadap keputusan pengambilan KPR pada Bank BTN Kantor Cabang Surabaya Bukit Darmo. 3)Service Quality berpengaruh positif dan signifikan terhadap keputusan pengambilan KPR pada Bank BTN Kantor Cabang Surabaya Bukit Darmo.

\section{SARAN}

Berdasarkan kesimpulan yang telah ditetapkan dapat diberikan beberapa saran sebagai berikut: 1) Peneliti selanjutnya yang akan meneliti PT. Bank Tabungan Negara (Persero), Tbk agar dapat melakukan penambahan variabel independen seperti kualitas produk dan promosi, 2) Pimpinan PT. Bank Tabungan Negara (Persero), Tbk agar dapat mempertahankan dan meningkatkan keberadaan merek (brand awareness), physical evidence dan service quality yang ada sehingga dapat keputusan pengambilan KPR dapat meningkat.

\section{DAFTAR PUSTAKA}

Ekhveh, A dan Darvishi, A. Z. 2015. The Impact of Brand Awareness on Re-purchase Intention of Customers With Trilogy of Emotions Approach (Case Study for Cell Phones). Applied mathematics in Engineering, Management and Technology, Vol. 3 No. 4, (25-30)

Foya, Anneth H. 2015. Effect Of Technology Based Customer Relationship Management On Service Quality In The Telecomunications Industry In Arusha, Tanzania. Thesis. Kenya: Kenyatta University.

Hasbun, Budiharti dan Endang Ruswanty. 2016. Komperasi Antara Kelompok Yang Melihat Iklan dan Tidak Melihat Iklan Dengan Moderasi Brand Awareness Terhadap Niat Beli (Studi Pada Commuter Line). Journal of Business Studies, Vol. 2 No. 1, (113)

Hidayah, Laely dan Prabawani, Bulan. 2016. Pengaruh Suku Bunga, Pelayanan Dan Kesadaran Merek (Brand Awareness) Terhadap Keputusan Pengambilan Kpr (Studi Pada Nasabah Pt Bank Tabungan Negara Kantor Cabang Semarang). Jurnal Ilmu Administrasi Bisnis, Vol. 5 No. 4, (458-465)

Infobank. 2020. Satisfaction Loyalty Engagement (SLE) Index. https://infobanknews.com/topnew s/ini-dia-bank-bank-dengannasabah-paling-loyal/ (Diakses pada 24 September 2020)

Komari, Ana, Indrasari, L. D., Tripariyanto, A. Y. dan Rahayuningsih, S. 2020. Analysis of SWOT Marketing Strategies and 7P Influence on Purchasing Decision. Journal of Physics: Conference Series. Vol. 1569 (1-9).

Kotler, Philip and Keller, Kevin Lane, 2016. Marketing Managemen, 15th 
Edition, England: Pearson Education,Inc.

Kotler, Philip dan Armstrong, Gary, 2014, Principles of Marketing, (Bob Sabran). 12th Edition, Jilid 1. Jakarta: Erlangga.

Laksmi, Andiorita T. 2019. Studi Tentang Pengaruh Kualitas Layanan, Brand Image Serta Implikasi Terhadap Keputusan Pembelian Produk Secara Online Pada Zoya Hijab. Thesis. Semarang: Universitas Diponegoro.

Marcelina, Jesse dan Billy, T. 2017. Pengaruh Marketing Mix (7p) Terhadap Keputusan Pembelian Pada Guest House Di Surabaya. Jurnal Hospitality dan Manajemen Jasa, Vol. 5 no 2. (1-16).

Menteri Keuangan. 1974. Surat Menteri Keuangan Nomor B-49/MK/I/1974 tentang "Lembaga Pembiayaan Kredit Perumahan", Jakarta.

Muthiah, Farah dan Setiawan, Budi. 2019. Pengaruh Brand Awareness, Brand Characteristic, Dan Emotional Branding Terhadap Keputusan Pembelian. Jurnal Ilmiah Manajemen Kesatuan, Vol 7 No. 2, (259-267)

Navaril, Ravita G. dan Usman, Dr. Osly. 2020. Effect Of Brand Awareness, Price, Product Quality Towards Decisions To Purchase Social Media Instagram. (https://ssrn.com/abstract=3637671) , diakses pada tanggal 20 September 2020 pukul 19.54.

Nazwirman dan Zain, Efendy. 2017. Pengaruh Kualitas Pelayanan Dan Harga Terhadap Loyalitas Konsumen Di Alfamart Cayur Kresek Tangerang. Journal of Economics and Business Aseanomics (JEBA), Vol. 2 no 2 Des (267-287).

PPDPP. 2020. Realisasi Penyaluran Dana FLPP tahun 20152020.https://ppdpp.id/realisasi-flpp- per-bank/. (Diakses pada 18 September 2020)

Qorizah, Alfia dan Prabowo, Prayudi S. 2019. Pengaruh Bauran Pemasaran Terhadap Keputusan Nasabah Mengambil Kpr Syariah Bank Jatim Syariah Surabaya. Jurnal Ekonomi Islam, Vol. 2 No. 2, (149161)

Rosica, Sanda A. D. dan Wibowo, Arif 2016. Pengaruh Persepsi Harga, Kepercayaan Merek, Dan Kualitas Pelayanan Terhadap Keputusan Pembelian Produk Kecantikan (Studi Pada Pelanggan London Beauty Center (Lbc) Di Kota Yogyakarta). Jurnal Manajemen Bisnis Indonesia (JMBI), vol 5 no. 3 , $(238-245)$

Sabrilia, Tinka, Andari, R. dan Abdullah, T. 2016. Pengaruh Physical Evidence Terhadap Keputusan Pembelian Konsumen Di Happy Cow Palasari Bandung (Survey pada Konsumen Di Happy Cow Palasari Bandung). Jurnal Gastronomy Tourism. Vol. 2 no 2. (180-188)

Sara, Fenny May, Ningsih, C dan Andari, R. 2019. Pengaruh Physical Evidence terhadap Keputusan Pembelian Konsumen di Café Infinito Culinery Bandung. Jurnal Gastronomi Pariwisata. Volume 3 Nomor 2, (6-18)

Sugiyono. 2019. Metode Penelitian Kuantitatif, Kualitatif, dan R\&D. Bandung: CV Alfabeta.

Tjiptono, Fandy, 2014. Strategi Pemasaran. Cetakan Ketiga, Yogyakarta: Penerbit Andi.

Top Brand Awards. 2020. Top Brand Index Kategori Banking dan Finance Produk KPR. https://www.topbrandaward.com/top-brand-index/?. (Diakses pada 18 September 2020)

Tran, Tuang Anh. Pham, N. T., Pham, K. V. dan Nguyen, L. C. T. 2020.

PERFORMANCE : Jurnal Bisnis \& Akuntansi Volume 11, No.2 September 2021 
The Roles of Health Consciousness and Service Quality toward Customer Purchase Decision. Journal of Asian Finance, Economics and Business, vol 7 no 8, (345-351).
Wibowo, Nadya E. 2017. Pengaruh Brand Awareness Terhadap Keputusan Pembelian (Studi Kasus Pada Yellow Truck Cabang Sunda Bandung Tahun 2017). eProceeding of Applied Science. Vol.3, No.2, Ags (230-249). 